\author{
Hanna Dzido \\ Mgr, Ekspert ds. analizy ryzyka \\ Urząd Lotnictwa Cywilnego \\ h.dzido@gmail.com; hdzido@ulc.gov.pl
}

DOI: 10.35117/A_ENG_19_01_03

\title{
Risk analysis in the supervision process
}

\begin{abstract}
The article deals with the theoretical and practical aspects of safety management in civil aviation. Presented the process of approach of Risk Based Oversight (RBO) and application of legal acts and documents necessary for oversight at particular levels (aviation organization, member state, European). One of the main activity of the implementation and effectiveness of the Safety Management System (SMS) management system in air organizations are the effective systems for occurrence reporting and the Just Culture idea. The article also includes an amendment to EU law - Regulation 2018/1139, so-called the new Basic Regulation (NBR - New Basic Regulation), which makes it possible to apply the law to state aviation aircraft carrying out military, customs, police, search and rescue, fire-fighting, border control and coastal protection or other public interest activities in favor of safety, interoperability and efficiency.
\end{abstract}

Keywords: Risk analysis; safety management system; Risk Based Oversight; Safety Performance Indicators

\section{Risk analysis in the supervision process}

Technological and technological advances in recent decades have allowed the use of new, more advanced systems and solutions in the aviation industry as well. Not only in aircraft, but also in aviation and aerodrome infrastructure or air traffic organization systems. Development is not possible without progress, but one of the conditions for the sustainable development of aviation is the safety of aviation operations, in which many aviation entities and organizations are involved. The commencement of operations in civil aviation requires that those entities and organizations - depending on the nature of the activity - obtain the necessary certificates, permits or approvals in the certification/verification process, which are issued in Poland in accordance with the provisions of the Act of 3 July 2002. The aviation law is within the competence of the President of the Civil Aviation Office.

Community aviation law does not regulate all aspects of European civil aviation or air transport, but points to a uniform and systemic approach to civil aviation, taking into account the interrelationship between safety and other technical areas of aviation regulations, including cybersecurity. The leading goal of establishing the European Union Agency Aviation Safety (EASA) and the creation of a uniform EU aviation law system was the liberalization of aviation. Valid for use from September 11, 2018, Regulation of the European Parliament and of the Council (EU) 2018/1139 of July 4, 2018, the so-called new NBR (New Basic Regulation) basic regulations on common rules in the field of civil aviation and the creation of the European Union Aviation Safety Agency as an act of Parliament and EU Council issued on the basis of art. 100 of the Treaty on the Functioning of the European Union (TFEU) is the so-called EU constitution of aviation law, constituting the basis for issuing detailed implementing regulations. By replacing Regulation (EU) 216/2008, it extends and establishes common goals and a framework for planning and implementing measures to ensure a high and uniform level of aviation safety. Effective implementation of these objectives is achievable through cooperation with the EU Member States and third countries whose aircraft performs operations using airports located in the EU Member States. 
In accordance with EU regulations (the basic regulation and implementing regulations dedicated to specific types of activities and adequate regulations of the Minister of Transport), conducting aviation activities in the territory of the European Union Member States is under the constant supervision of the European Aviation Safety Agency (EASA) and national authorities supervision. At the European level, EASA oversees a total of 32 countries (28 EU Member States plus Norway, Liechtenstein, Iceland, and Switzerland).

Functioning on the same principles - free competition in force in the EU forces aviation organizations to operate in the most effective manner, which leads to a continuous search for savings. However, there is no permission to under any circumstances take place at the expense of lowering safety standards, passengers or the natural environment. Implementing acts - special regulations supplementing the basic regulation impose an obligation to maintain, among others technical harmonization and aviation safety, which are regulated in specific areas in specific areas, for example: performing air operations, aircrew licensing, airport operations and air navigation services, design and manufacture of aeronautical products, technical maintenance of aircraft (Figure 1) created based on ICAO Annex 19, dedicated to civil aviation safety management.

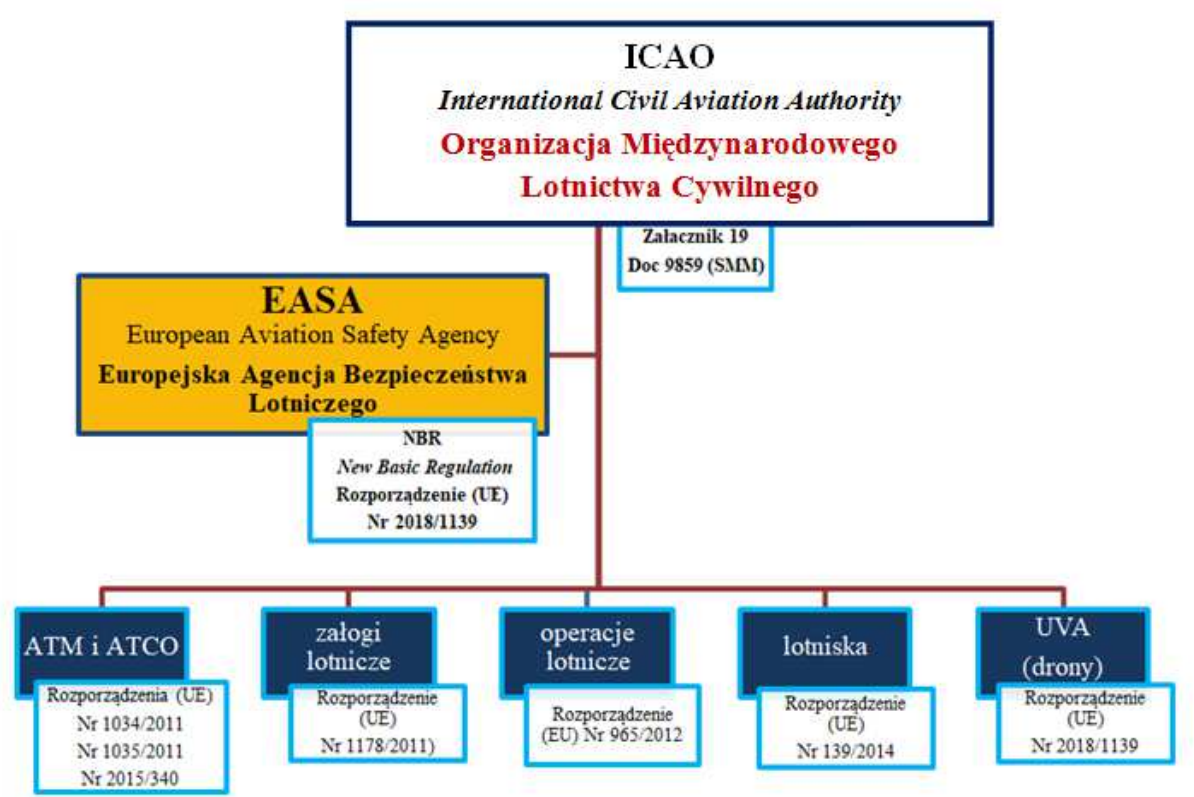

1. Legal regulations including risk analysis at particular levels

The Agency, as the competent authority for certification and supervision (issue of specific certificates and exemptions), provides for the possibility of amending the principles set out in delegated and implementing acts to ensure compliance and acceptable levels of civil aviation safety in the European Union Member States.

The main tasks of the Agency include first of all the assistance of the EU Commission in the preparation of draft legal acts concerning safety in civil aviation. To this end, the Agency issues opinions and recommendations addressed to the Commission. The agency also performs its own tasks, e.g.:

- issuing certificates for aviation products in the field of safety and environmental protection (e.g. aircraft, engines);

- approval and supervision of aircraft design and production organizations (certification of individual aircraft is the responsibility of the authorities of the Member States)

- keeping the so-called black list of air carriers. 
The Agency also has the authority to conduct inspections, training, and programs in the European Union Member States and to collect data and conduct research to improve aviation safety.

The supervision system in Poland is organized in accordance with the applicable regulations:

- the minister responsible for transport is the supreme governmental body in the field of civil aviation

- the central government administration body in the field of civil aviation in accordance with art. 20 and 21 of the Aviation Act is the President of the Civil Aviation Office, performing the function of the air traffic administration authority and aviation authority as well as the aviation authority within the meaning of international agreements and regulations. The Act clearly indicates that the President, while exercising his office, does not violate the establishment or powers of the European Aviation Safety Agency (EASA);

- an independent body conducting or supervising safety investigations by organizations in accordance with Article 17 of the Aviation Law is the State Commission on Aircraft Accident Investigation (PKBWL).

The basic importance for maintaining the required level of security and its continuous improvement in civil aviation in the face of emerging threats is the application by EU Member States uniform solid principles of safety management, continuous identification of accompanying risks and anticipation of new security threats.

To preserve this uniformity, it was necessary to establish a common planning framework and implementing measures to improve safety.

To this end, an aviation safety plan and a European aviation safety program have been developed at EU level, and it was the responsibility of each Member State to develop a national safety program in line with the requirements of Annex 19 to the Convention on International Civil Aviation, signed in Chicago on December 7, 1944 so-called the Chicago Convention on 'Security Management.' The document accompanying the national program is a plan in which the Member State describes actions taken to limit the identified safety risk. The objectives set out in these documents should be reflected in the activities related to the development and implementation of the appropriate plan and supervisory program for subordinate organizations and aviation entities. Their implementation, together with the provision of modifications to current challenges or necessity, should ensure the maintenance of a high level of safety of aviation operations and the activities of entities supporting the implementation of air transport. Exercising oversight means on-going verification of compliance of operations with regulations, analysis of data held, and conducting controls, audits, and inspections:

- planned and cyclical - carried out in accordance with the supervisory program approved by the President of the ULC for entities that are necessary to maintain certificates, permits/approvals;

- unplanned (ad hoc) - resulting from the current needs of control to maintain an adequate level of security

and all planned and ad hoc activities undertaken to popularize the security culture. In Poland, the inspections and audits are carried out in accordance with national regulations - the Aviation Law and executive acts (including the Regulation of the Minister of Infrastructure of September 2, 2003, on compliance monitoring and civil aviation decisions), adapted to EU regulations in adequate fields of activity of aviation organizations. 
The dynamically growing demand for services of the air transport market, as well as the development of technology and technologies, has been translated into the use and application of newer solutions and technologies in aviation, which entails the emergence of new types of threats (including terrorism). As a result of the growing scale of flight operations and the perception of further threats and risks associated with them, it has evolved the approach and way of exercising supervision. At every level: international (ICAO), European (EASA) and national (Member States) and subsequent stages - from the certification process to supervision - the element of risk assessment is indicated as one of the basic ones. The risk relates to the nature of operations, the type of operations performed, the financial situation of aviation organizations and the assessment of their ability to meet and maintain safety standards.

RBO (Risk Based Oversight) supervision is a combination and assessment of the level of compliance with regulations and the result of the organization's risk profile assessment and safety performance. Focuses on risk management and optimal adjustment of the supervisory program to the organization. The introduction of a risk-based approach involves adjusting and optimizing the supervision exercised at individual levels. Not only the supervisory authorities but also aviation organizations that implement the provisions of existing legal acts are required to assess and manage risk.

The RBO approach requires the implementation and development of an SMS (Safety Management System) in aviation organizations (carriers, producers, service organizations, airports) and close cooperation with supervisory authorities in the Member States. It is an evolution from a traditional detailed description of each security principle to an effective SMS (possession and implementation of four SMS components - diagram below), switching to a system based on properly implemented SMS by aviation organizations, designated safety indicators (SPI - Safety Performance Indicators): own (by organizations) and national (at state level), monitoring their levels and striving for set values of indicators at both EU and national level as well as individual entities of the aviation sector.

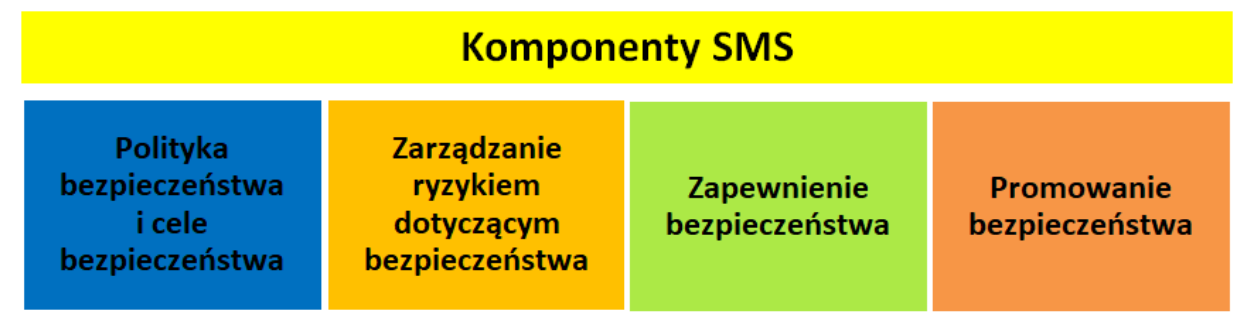

2. SMS elements in aviation organizations

The change in perception led to a change in the way of behavior for maintaining an appropriate state of security and supervision over organizations involved in the air operations process, i.e. monitoring security indicators. Legal regulations introduced the obligation to verify the levels of safety indicators at all levels: aviation organizations, the Member States and Europe. Thanks to the combination of activities of aviation entities with the activities of national supervisors, greater complexity in the approach is obtained to the issue of safety management.

In relevant documents issued at individual levels: international/global, European and national (ICAO, EASA, member states), threats and actions to be taken to reduce risk are identified and indicated (Figure 3). 


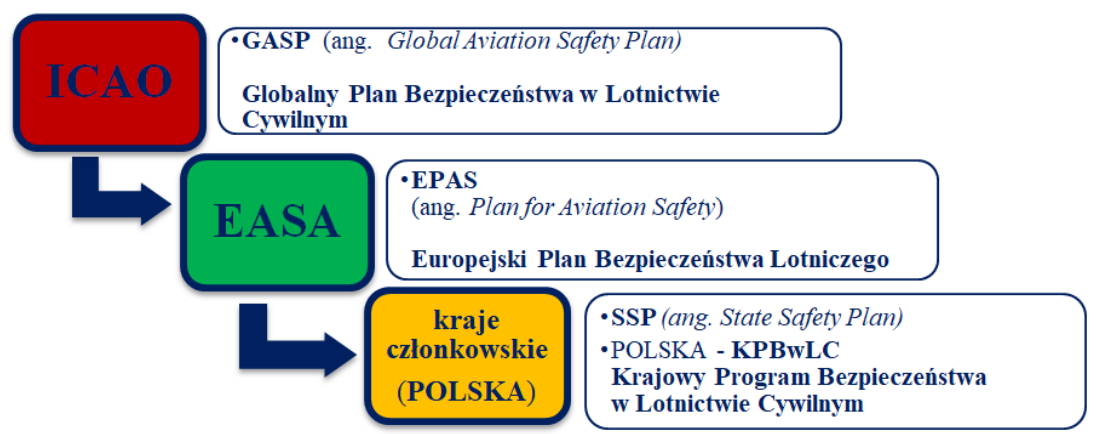

3. Documents regarding programs/safety plans at individual levels

Taking into account the provisions of "higher" documents (GASP and EPAS), member countries are obliged to develop adequate plans and solutions at the national level.

The question of what the change has to be served, the answers indicate, among others,:

- at the organization level:

- verification of the implementation status and correctness of SMS operation;

- collecting information and data to create databases used to conduct analyzes and forecasts;

- early identification of threats;

- developing and undertaking actions limiting the possibility of occurrence and materialization of threats (development of barriers at the analysis stage);

- at the national level:

- maintaining an adequate level of security;

- optimization of supervision at national level;

- transition from a reactive to predictive approach - counteracting the possibility of threats rather than reacting to situations that have already occurred;

- - avoiding hazards and building barriers at the stage of analyzes (in Poland BowTie method developed, among others, for an easy to understand and transparent graphic presentation of risk scenarios accompanying aviation events) ULC uses the Bow-Tie method to control from the perspective of the aviation system the hazard areas defined in the National Security Plan in Civil Aviation). Examples of the application of the method have been published on the Office's website;

- participation in co-creating supervision standards at the international and global level (EASA, ICAO);

- creating databases to conduct analyzes and forecasts, identification of high risk areas that require special attention in exercising supervision (intensification and focusing on sensitive areas / sections of the organization's activities));

- at EU/international level:

- standardization of the supervisory approach at international and global level EASA, ICAO;

- maintaining appropriate standards in the aspect of civil aviation safety;

- creating conditions for cooperation between various types of aviation (civil, military, state) for security;

- identification of threats and areas of high risk in order to take actions to limit them; 
- using the collected data at national levels to undertake aviation safety activities;

- using experience and good practices to improve tools

- $\quad$ and the quality of supervision;

- promotion and encouragement to undertake work that is important for security.

The scheme of behavior in relation to threats and activities associated with them at each level is virtually the same (Figure 4). Possible differences will result from the specificity and nature of the business, identified risks and the level of detail and advancement of the analyzes.

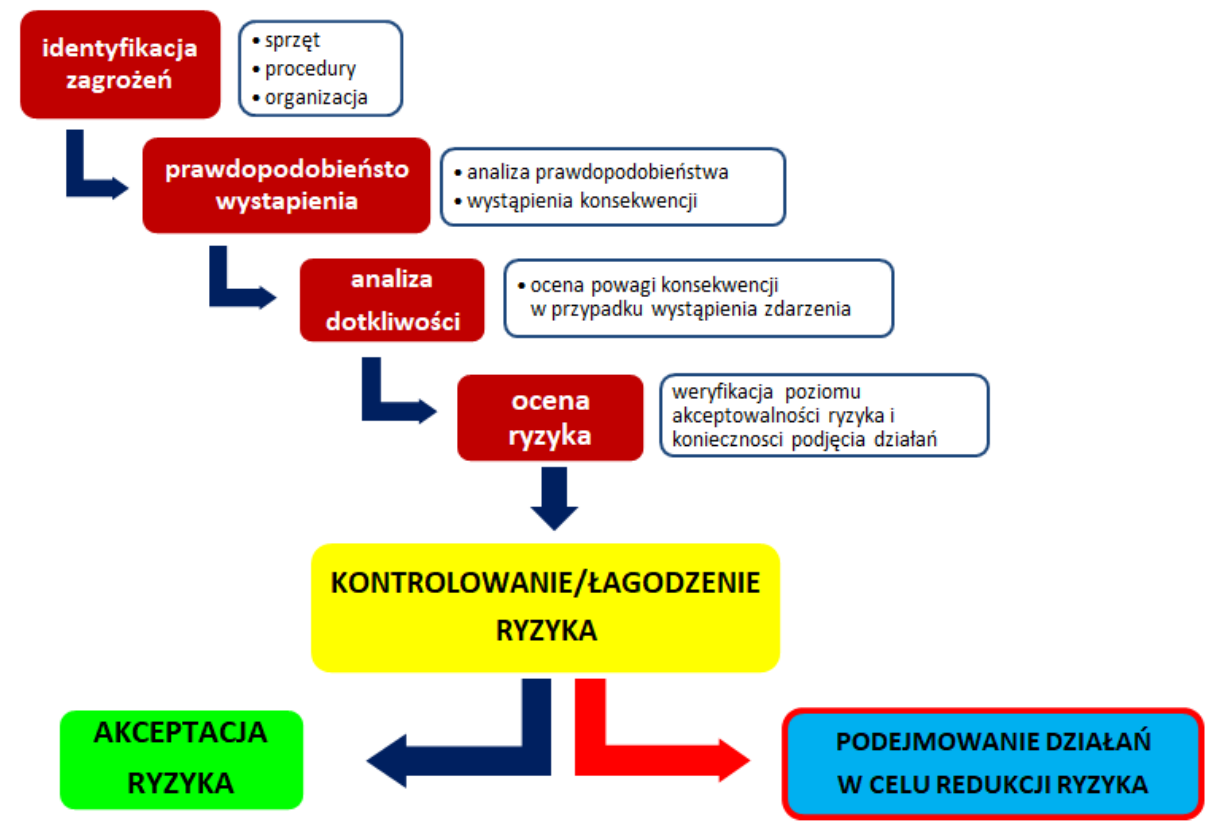

4. The process of activities within SMS - hazard identification and risk management

As part of the support and preparation for the full implementation and unification of the RBO-based oversight approach, EASA released Practices for risk-based oversight on November 22, 2016. The document was posted on the Agency's website, it was published in accordance with art. 5 par. 3 of Regulation (EU) No 628/2013, in which "the Agency shall provide the competent authorities of the Member States with relevant information to support the uniform implementation of the applicable requirements.

Due to the fact that the document is not legally binding, it can be treated as a guide to the application and use of analysis methods and their results to maintain a high level of security applied by supervisory authorities of some member states..

The process of transition to supervision based on risk analysis requires proper preparation of systems and procedures and necessary adaptation of actions to new challenges and fulfillment of requirements. In Poland, the President of ULC in the Report on the implementation of the Civil Aviation Office's business plan for 2017, indicates almost a full implementation of the implementation plan of the risk-based supervision system (relative to the 2017 plans). The effect of actions aimed at this direction was the development and publication on the website of ULC in August 2016 of the National Program of Safety in Civil Aviation (KPBwLC). The document was prepared at the level of the Civil Aviation Office, agreed and accepted by the Ministry of Infrastructure and Construction and approved and signed by the Minister of Infrastructure and Construction on August 4, 2016. It indicates the 
areas of threats that have been or will be included in the procedure of specific analyzes and special supervision of ULC President. The aim of the program is to identify threats, assess them and develop effective mitigating actions.

KPBwLC is annexed to the National Security Plan (KPB). Over the past two years, two documents have been published relating to the identification of threats and safety indicators:

1. National Security Plan for 2017-2020 (the first version of the document);

2. National Security Plan for 2018-2021 (second verified version of the document)

The currently used document from 2018, in addition to indicating the threats, sets up a set of Level Safety Indicators (SPIs), whose designation by the aviation organizations subject to the obligation to measure the Safety Performance level, is imposed by separate EU specific regulations. SPI indicators determined at the national level and presented to the aviation community at the KPB are to serve organizations in order to compare their own indicators to their counterparts at the national level, and ultimately strive to achieve and maintain the required level of safety - ALoSP - Acceptable level of safety performance.

Ongoing monitoring of the security situation and possible risks also applies to imperfections of the legal system and the resulting complications or mutual exclusions, as well as the emergence of new technologies.

The indicators presented in the KPBwLC were determined based on aviation events reported to the State Commission on Aircraft Accidents (PKBWL) and the Civil Aviation Office as part of the Polish system for collecting, storing, analyzing, assessing and processing data on aviation incidents and stored in the ECCAIRS system (European Central Aviation Event Coordination System/European Co-ordination Centre for Accident and Incident Reporting Systems.

What is important and worth emphasizing NBR 2018/1139 introduces a mechanism that allows the application of principles resulting from EU aviation safety regulations, including in military or state aviation (border guards).In the process of changing the approach to the surveillance system from reactive to predictive, it is extremely important to promote and encourage reporting of events that constitute the main source of knowledge about occurring and potential threats. Based on the collected information and data at the level of aviation organizations and at the national level, real and it becomes possible to conduct analyzes and take actions and then verify their effectiveness.

After signing by the European Commissioner for Transport and representatives of the aviation community on 1 October 2015, the European Corporate Just Culture Declaration followed the Polish aviation industry involved in security matters. On October 27, 2015, during the Conference on Civil Aviation Safety, the Declaration of cooperation regarding the implementation of Just Culture took place. The document is open-ended and sets out a number of basic principles to encourage personnel involved in safety-relevant work to report irregularities and adverse events without worrying about the consequences. The declaration was signed by representatives of the authorities and supervisory authorities and the rule of law. The idea of the Just Culture philosophy is to increase the awareness of the aviation environment in terms of threats resulting from mistakes made, which accompany everyday work and functioning of the organization as well as cooperation between them. The goal is to increase the number of reported events within the obligatory and a voluntary accident reporting system also regarding shortcomings in systems, procedures, and routine post factum activities at the level of the organization.

Cooperation with supervision and exchange of experiences in the environment is a path and the platform for developing a common approach to matters related to security. The attitude of responsibility and maturity on the part of employees and managers of aviation organizations together with the desire to engage in cooperation create good conditions and perspective to work out real solutions. Regulation No. 386/2014 of the European Parliament 
and of the Council of 3 April 2014 on the reporting and analysis of civil aviation events and follow-up activities underlines the importance and necessity to strengthen cooperation between state institutions and the aviation environment in the field of Just Culture. Mutual learning on the experience of others will certainly have a positive impact on raising awareness and shaping positive and responsible attitudes towards security. At the same time, it should be emphasized and pointed out that there is no consent to use Just Culture for targeted protection and conscious violation of regulations and procedures.

\section{Source materials}

[1] Podręcznik Zarzadzania Bezpieczeństwem (SSM), wyd. 3, Montreal 2013, Doc 9859. Tekst zawarty w dokumencie: Wytyczne nr 11 Prezesa Urzędu Lotnictwa Cywilnego z dnia 24 listopada 2015 r. w sprawie wprowadzenia do stosowania wymagań ustanowionych przez Organizację Międzynarodowego Lotnictwa Cywilnego (ICAO), Doc 9859, Dz. Urz. ULC poz. 64.

[2] Ustawa z dnia 3 lipca 2002 r. Prawo lotnicze, Dz. U Nr 1183, 1629, 1637 z 2018 r.;

[3] Rozporzadzenie Parlamentu Europejskiego i Rady (UE) 2018/1139 z dnia 4 lipca 2018 r. $w$ sprawie wspólnych zasad $w$ dziedzinie lotnictwa cywilnego i utworzenia Agencji Unii Europejskiej ds. Bezpieczeństwa Lotniczego oraz zmieniające rozporządzenia Parlamentu

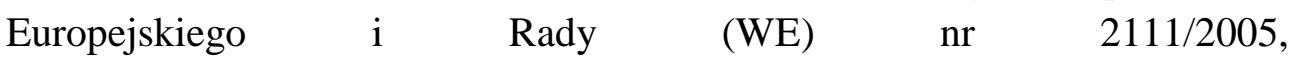
(WE) nr 1008/2008, (UE) nr 996/2010, (UE) nr 376/2014 i dyrektywy Parlamentu Europejskiego i Rady 2014/30/UE i 2014/53/UE, a także uchylające rozporządzenia Parlamentu Europejskiego i Rady (WE) nr 552/2004 i (WE) nr 216/2008 i rozporządzenie Rady (EWG) nr 3922/91;

[4] Traktat o funkcjonowaniu Unii Europejskiej, Dziennik Urzędowy C 326 , 26/10/2012 p. 0001 - 0390;

[5] Rozporzadzenie wykonawcze Komisji (UE) nr 628/2013 z dnia 28 czerwca 2013 r. $w$ sprawie metod pracy stosowanych przez Europejska Agencje Bezpieczeństwa Lotniczego przy prowadzeniu inspekcji standaryzacyjnych $i$ monitorowaniu stosowania przepisów rozporzqdzenia Parlamentu Europejskiego $i$ Rady (WE) nr 216/2008 oraz uchylające rozporządzenie Komisji (WE) nr 736/2006;

[6] Sprawozdanie z wykonania planu działalności Urzędu Lotnictwa Cywilnego za rok 2017 dla dziatu/działów administracji rządowej, Urząd Lotnictwa Cywilnego, Warszawa, 1 marca 2018;

[7] Krajowy Program bezpieczeństwa w Lotnictwie Cywilnym, Urząd Lotnictwa Cywilnego, wyd.1, Warszawa, sierpień 2016 r.

[8] Krajowy Plan Bezpieczeństwa na lata 2017 - 2020, Urząd Lotnictwa Cywilnego, Warszawa, 2017;

[9] Krajowy Plan Bezpieczeństwa na lata 2018 - 2021 Urząd Lotnictwa Cywilnego, Warszawa, 2018;

\section{Websites:}

1. www.icao.int

2. www.easa.europa.eu

3. www.gov.pl/web/infrastruktura

4. www.ulc.gov.pl 